\title{
Europe weighs a carbon tax
}

\section{London}

THE member states of the European Communities (EC) must decide whether they are prepared to take real - and possibly costly - action to meet their stated commitment to stabilize the EC's emissions of carbon dioxide at 1990 levels by 2000 . Last week, to that end, the European Commission proposed a formal draft directive to impose an EC-wide tax that would add $\$ 10$ to the price of a barrel of oil by the turn of the century.

The proposed tax would penalize both the burning of carbon and the use of energy in general. The \$10-per-barrel oil surcharge would be split equally between a tax on the fuel's energy content and a separate levy on the amount of carbon dioxide produced when the oil is burned. Carbon-rich fuels, such as coal, would be taxed more heavily, but even nuclear-generated electricity would be subject to the energy levy; the only exemption would be for renewable energy sources. The Commission's intention is to introduce the tax gradually, starting with a $\$ 3$ tax on a barrel of oil in 1993 and increasing by $\$ 1$ a year over the rest of the decade.

In Brussels, officials under EC environment commissioner Carlo Ripa di Meana have been developing the proposal for many months, and the version given the full Commission's backing last week contains a number of 'sweeteners' designed to lessen opposition from the member states. Many EC member governments would have objected to the idea of a new tax swelling the Commission's coffers, but the new proposal requires that the carbon/energy tax be fiscally neutral: the tax would be collected by the member states' governments themselves, and the extra income should be offset by reductions in other national taxes.

Energy-intensive industries relying heavily on international trade - such as chemicals, iron and steel, and paper manufacturing - may also be protected from the tax if the EC's international competitors do not take similar measures. According to one Brussels source, these industries could be exempted from the tax altogether if the United States refuses to adopt a target to stabilize its carbon dioxide emissions.

But even with these concessions to

\section{CLARIFICATION}

SHIRLEY McGreal, chair of the International Primate Protection League, asks that it be made clear that she did not (as reported in Nature 353, 199; 19 September 199 () ask recipients of her letter "if they should be doing business with" Matthew Block, but that she merely asked them to "peruse" a notice issued by the Centers for Disease Control to Worldwide Primates Inc. listing 46 instances of non-compliance with quarantine regulations. ensure international competitiveness, the tax is expected to have some damaging economic effects, including an increase in the EC's annual rate of inflation by as much as 0.5 per cent. This may deter some EC member governments from supporting the measure. British environment minister David Trippier said last week that Britain is not yet ready to support the introduction of a carbon tax, and he suggested that two-thirds of EC member states back the British position. Some governments, such as the French, are violently opposed to any EC interference in national taxation policy, he added. But with the Netherlands, a strong supporter of the carbon tax proposal, holding the EC presidency, the draft directive is certain to be high on the agenda when the member states' environment and energy ministers meet over the next few months.

Officials in the Commission's environment directorate-general reject Trippier's assessment that the proposal lacks support, and argue that the tax is necessary if the EC's commitment to stabilize its carbon dioxide emissions by 2000 is to be met. According to the Commission's economic models, an \$18 surcharge on a barrel of oil would be needed to meet this target, although Ripa di Meana's staff believe that the $\$ 10$ levy can do the job if combined with other measures, such as stricter standards for energy efficiency.

Whether or not the EC member states accept the new tax, the EC must still pursue its efforts to convince the US government to adopt a target to stabilize its carbon dioxide emissions. (Stabilizing emissions is itself only a small first step towards halting the build-up of carbon dioxide in the atmosphere, and so preventing the expected global warming). The Bush Administration has repeatedly rejected the notion of emissions targets, arguing that the scientific evidence for carbon-dioxide-driven global warming is still too tentative to serve as a basis for firm commitments to specific reductions in greenhouse gases.

Peter Aldhous

\section{Research given priority in new French budget}

\section{London}

SCIENCE fares well in the French national budget for 1992, announced by the Council of Ministers late last month. With total public expenditure due to increase by only 3.1 per cent (near the predicted rate of inflation over the coming year), the proposed FF51,000 million budget for civil research and devel. opment is 7 per cent more than in 1991.

Officials at the Ministry of Research and Technology, which is responsible for just over half of French government spending on civil science, say the French government is making research, education and the environ-

French government spending on civil $R \& D$

ment its main priorities, and they expect the budget to be approved by the parliament with no major changes. The new budget marks a return to steady growth in French science spending, after a hiccup earlier this year when some FF1,000 million of the planned 1991 research budget was trimmed by the government (Nature 350, 181; 21 March 1991). Those cuts, which affected the entire spectrum of public spending, were made necessary by the recession and expenditure on the Gulf War, and are not expected to be repeated next year.

Academic researchers should be happy with the proposed 1992 budget, which gives
FF11,852 million to the Centre National de la Recherche Scientifique, the principal government agency supporting basic scientific research, 8.1 per cent more than its allocation for 1991. But the real winners are French industrial scientists, who will receive $\mathbf{F F 6 , 1 0 0}$ million, 17.5 per cent more than in 1991. In addition, tax credits given to companies carrying out research not included in the budget figure - are set to rise by almost 10 per cent, to a total of FF4,500 million. Already, the French government's generous support for industrial research has already caused some raised eyebrows in other European Communities states, which fear that French companies may gain an unfair competitive advantage (Nature 353, 98; 12 September 1991).

There is one area of stagnation in the new research budget, however. The French atomic research agency - traditionally strong, given the country's 70 per cent reliance on nuclear-generated electricity - faces a budget that will grow by only 0.3 per cent over its 1991 allocation, to FF6,300 million. After inflation is taken into account, France's nuclear researchers will find themselves with less money to spend.

Peter Aldhous 